\title{
KARAKTERISTIK ISOLAT Proteus mirabilis PADA SPESIMEN URIN DI RSUP SANGLAH SELAMA TAHUN 2018 - 2019
}

\author{
I Nyoman Arnatha*, Ni Luh Ranthi Kurniawathi**, Komang Januartha Putra \\ Pinatih*** $^{* * *}$ \\ Program Pendidikan Dokter Spesialis Mikrobiologi Klinik, Fakultas Kedokteran \\ Universitas Udayana, Jl. PB Sudirman Denpasar (80232), Bali \\ Email : dr.januarthapinatih@gmail.com
}

\begin{abstract}
ABSTRAK
Proteus mirabilis merupakan salah satu bakteri penyebab utama infeksi saluran kemih yang dapat memicu pembentukan kristal atau batu saluran kemih (BSK). Pemberian antibiotik yang adekuat dapat menurunkan resiko pembentukan BSK. Tujuan penelitian ini untuk menentukan karakteristik Proteus mirabilis yang diisolasi dari spesimen urin dan pola kepekaannya terhadap antibiotik. Penelitian ini merupakan penelitian deskriptif yang dilakukan secara potong lintang dengan kurun waktu 2 tahun (1 Januari 2018 sampai 31 Desember 2019) di RS Sanglah, Denpasar, Bali. Semua kultur urin dengan Proteus mirabilis dimasukkan dalam penelitian. Identifikasi bakteri dan sensitivitas terhadap antibiotik dilakukan dengan menggunakan mesin Vitek®2 Compact (BioMerieux). Dari 4.094 spesimen urin yang dikultur, didapatkan 49 isolat Proteus mirabilis dengan karakteristik pasiennya adalah : $49 \%$ laki-laki dan $51 \%$ perempuan. Usia mayoritas adalah 18-65 tahun (77.6\%). Isolat yang menunjukkan adanya BSK adalah 13 isolat (26.5\%) dengan lokasi batu paling banyak berada di ginjal sejumlah 9 isolat (69.2\%). Rerata jumlah leukosit adalah $13.88 \times 10^{3} / \mu \mathrm{L}( \pm 7.56)$. Rerata persentase neutrofil adalah $67.24 \%( \pm$ 25.38). Rerata kadar Blood Urea Nitrogen (BUN) adalah $27.25 \mathrm{mg} / \mathrm{dL}( \pm 26.66)$. Rerata kadar serum kreatinin adalah $2.64 \mathrm{mg} / \mathrm{dL}( \pm 9.15)$. Persentase Multidrug Resistant Organisms (MDRO) sejumlah 38.8\%. Hasil sensitivitas Proteus mirabilis terhadap amikacin sebesar 100\%. Penelitian menunjukkan bahwa bakteri Proteus mirabilis cenderung mampu untuk membentuk kristal / BSK. Marker infeksi, fungsi ginjal pasien, dan sensitivitas terhadap antibiotik, tidak menunjukkan perbedaan yang signifikan antara isolat dengan BSK dan tanpa BSK.
\end{abstract}

Kata Kunci : Proteus mirabilis, batu saluran kemih, MDRO

\section{ABSTRACT}

Proteus mirabilis is one of the main causes of urinary tract infections which can lead to formation of urinary tract stones. Adequate antibiotics can reduce the risk of stone 
formation. The aim of this study was to determine characteristics of Proteus mirabilis isolated from urine specimens and its sensitivity to antibiotics. This was a cross-sectional descriptive study with a period of 2 years (1 January 2017 to 31 December 2018) in Sanglah Hospital, Denpasar, Bali. All urine cultures with Proteus mirabilis were included in this study. Identification and sensitivity test were conducted using Vitek-2 Compact machine (BioMerieux). Out of 4,094 urine specimens were cultured, in which 49 isolates of Proteus mirabilis were obtained. Characteristics of patients as follows $49 \%$ male and $51 \%$ female. The majority of the age is 18-65 years (77.6\%). Isolates that showed the presence of stone were 13 isolates (26.5\%) with location of the stones were mostly in the kidneys (9 isolates/69.2\%). The mean leukocyte count was $13.88 \times 10^{3} / \mu \mathrm{L}( \pm 7.56)$. The average percentage of neutrophils was $67.24 \%$ ( \pm 25.38$)$. The mean Blood Urea Nitrogen levels was $27.25 \mathrm{mg} / \mathrm{dL}( \pm 26.66)$. The mean serum creatinine level was $2.64 \mathrm{mg} / \mathrm{dL}$ ( \pm 9.15). Percentage of Multidrug Resistant Organisms was 38.8\%. All of isolates were sensitive to amikacin (100\%). This study showed that Proteus mirabilis might be as a cause of urinary tract stone. Infection markers, patient kidney function, and sensitivity to antibiotics did not show a significant difference between isolates with and without stones.

Keywords: Proteus mirabilis, urinary tract stones, MDRO.

\section{PENDAHULUAN}

Proteus mirabilis merupakan bakteri batang gram negatif yang termasuk dalam golongan Enterobacteriaceae. Bakteri ini tersebar luas di lingkungan, sebagai flora normal di saluran cerna dan dikenal bersifat patogen oportunistik (Mahon, CR; Lechman, 2019). Isolat Proteus mirabilis sering ditemukan dalam praktek klinis dan merupakan salah satu bakteri penyebab utama infeksi saluran kemih (ISK) (Armbruster et al., 2018). Data di USA menunjukkan bakteri ini bertanggung jawab atas 3\% kejadian HAIs (Healthcare Associated Infections), khususnya ISK akibat pemakaian kateter (Mahon, CR; Lechman, 2019). Sedangkan studi di RS Guangzhou, Cina menyatakan 5,2\% kejadian ISK oleh karena Proteus mirabilis, sehingga dimasukkan dalam 4 uropatogen utama selain Escherichia coli (48.7\%), Klebsiella pneumoniae (10.4\%), dan Enterococcus faecalis $(8.7 \%)$ (Chen et al., 2018).

Bakteri Proteus mirabilis dapat masuk ke saluran kemih secara ascenden, menyebabkan infeksi di saluran kemih bagian bawah ataupun atas. Bakteri ini dapat menginfeksi tubulus ginjal proksimal dan dapat menyebabkan glomerulonefritis akut, 
khususnya pada pasien dengan defek saluran kemih dan riwayat pemakaian kateter (Mahon, CR ; Lechman, 2019).

Pada proses uropatogenesis, Proteus mirabilis dapat mengekspresikan berbagai faktor virulensi, seperti adhesins, flagela, toksin, enzim, quorum sensing dan faktor penghindaran imun (Baldo et al., 2014). Proteus mirabilis mampu memproduksi enzim urease yang dapat menghidrolisis urea menjadi ammonia $\left(\mathrm{NH}_{3}\right)$ menyebabkan urin bertambah basa (alkali). Jika tidak segera ditanggulangi, bertambahnya tingkat kebasaan dapat memicu pembentukan kristal struvit dan karbonat apatit, batu saluran kemih atau batu ginjal (kalkuli) (Brooks et al., 2019; Li et al., 2002; Norsworthy \& Pearson, 2017).

Terbentuknya biofilm kristal ini menjadi masalah dalam kejadian ISK terkait pemakaian kateter, dimana kristal ini dapat menyumbat kateter yang disebabkan oleh kerak biofilm. Pasien dengan kerak kateter pada infeksi Proteus mirabilis akan berkembang sekitar $62 \%$ menjadi batu saluran kemih (BSK) (Jacobsen \& Shirtliff, 2011). Perlu waktu 4-6 minggu dari mulai infeksi untuk terbentuknya BSK (Bichler et al., 2002). Prevalensi BSK karena infeksi menurun dalam 30 tahun terakhir, tetapi prognosisnya masih buruk. Angka mortalitas dalam 20 tahun pada BSK infeksi sebesar $28 \%$ tanpa pembedahan dan $7 \%$ bila dilakukan pembedahan (Norsworthy \& Pearson, 2017).

Proteus mirabilis dengan mudah dapat diidentifikasi dari laboratorium klinis karena karakteristik koloninya yang bisa membentuk gambaran "swarming" pada media non selektif seperti SBA (Sheep Blood Agar) (Mobley \& Belas, 1995). Fenomena "swarming" ini terjadi karena adanya diferensiasi multiselular pada media padat, dari sel vegetative standar (swimmer) menjadi sel polyploid dengan banyak flagella yang memanjang (swarmer). Selain itu juga terjadi sinyal antar sel (interaksi multiselular) (Armbruster et al., 2018; Mahon, CR ; Lechman, 2019). Sel-sel swarmer ini juga menghasilkan bau khas yang terkait dengan koloni Proteus, kadang-kadang digambarkan seperti bau cokelat yang dibakar (Brooks et al., 2019; Mahon, CR ; Lechman, 2019).

Strain Proteus sangat bervariasi kepekaannya terhadap antibiotik. Proteus mirabilis umumnya masih sensitif terhadap antibiotik golongan penisilin (misalnya, ampisilin dan amoksisilin), trimethoprim - sulfametoksazol, sefalosporin, aminoglikosida, dan imipenem (Brooks et al., 2019). Studi di Taiwan menunjukkan dalam dekade terakhir terjadi penurunan kepekaan yang signifikan pada Proteus mirabilis terhadap sefalosporin generasi ke-3 dan ciprofloxacin. Prevalensi bakteri 
penghasil extended-spectrum betalactamases (ESBL) tetap stabil tetapi Proteus mirabilis penghasil AmpC $\beta$ laktamase meningkat secara signifikan (Wang et al., 2014). Sedangkan untuk intrinsik resistan dari Proteus mirabilis adalah antibiotik golongan tetrasiklin/ tigesiklin, polimiksin $\mathrm{B}$, colistin dan nitrofurantoin (Al-bassam, 2013; Weinstein, 2020).

$$
\text { Mayoritas uropatogen pada }
$$
pasien dengan batu memiliki resistansi yang tinggi $(>20 \%) \quad$ terhadap fluoroquinolon, ceftriaxone, ceftazidime, cefepime, penisilin, sulfonamide dan monobactam (Chen et al., 2018). Pada kasus ISK dengan adanya batu, terapi selain antibiotik adalah eradikasi batu secara komplit dengan cara Shock Wave Litotripsy atau operasi pengangkatan batu (Schaffer \& Pearson, 2016). Jika tidak mendapat terapi yang tepat, BSK ini dapat terus berkembang menjadi batu staghorn yang merusak ginjal dan memungkinkan terjadi sepsis yang mengancam nyawa (Torzewska \& Rózalski, 2015).

\section{BAHAN DAN METODE}

Penelitian ini adalah penelitian deskriptif retrospektif potong lintang dalam periode 2 tahun dari Januari 2018 hingga Desember 2019. Penelitian dilakukan di Instalasi Mikrobiologi Klinik RSUP Sanglah Denpasar Bali.
Data merupakan data sekunder, diambil dari rekam medis pasien pada sistem informasi elektronik RSUP Sanglah (SIMARS). Catatan medis elektronik juga digunakan untuk mengumpulkan karakteristik demografi pada pasien.

Pemilihan sampel dilakukan dalam kurun waktu tersebut yang memenuhi kriteria inklusi yaitu semua pemeriksaan kultur urin dengan hasil identifikasi dari mesin Vitek ${ }^{\circledR} 2$ Compact : terisolasi bakteri Proteus mirabilis, disertai adanya pemeriksaan radiologi (USG abdomen, CT Scan abdomen dan atau foto BOF), pemeriksaan darah lengkap dan pemeriksaan kadar Blood Urea Nitrogen (BUN) dan Serum Kreatinin pasien. Untuk kriteria eksklusinya adalah hasil kultur VITEK®2 yang tidak sesuai kriteria inklusi, hasil kultur yang berulang pada pasien yang sama, dan hasil kultur yang berasal dari pasien rumah sakit lain (Leber, 2016).

Ada tidaknya batu pada saluran kemih dapat dilihat dari hasil pemeriksaan radiologi. Marker infeksi dilihat dari kadar leukosit dan persentase neutrofil pada pemeriksaan darah lengkap. Fungsi ginjal dapat dilihat dilihat dari kadar Blood Urea Nitrogen (BUN) dan serum kreatinin pasien. Data terkait hasil pemeriksaan penunjang (pemeriksaan radiologi dan laboratorium) pasien juga diambil dari 
catatan medis pasien di SIMARS. Semua data yang diperoleh, kemudian dianalisis dan dikerjakan menggunakan perangkat lunak SPSS versi 24.

\section{HASIL}

Dari 4.094 spesimen urin yang dikultur dalam kurun waktu 2 tahun pada 1.756 pasien (1 Januari 2018 sampai 31 Desember 2019) di RS Sanglah, didapatkan 49 sampel yang terinfeksi bakteri Proteus mirabilis. Komposisi pasien terdiri atas 24 orang (49\%) lakilaki dan 25 orang (51\%) perempuan. Usia mayoritas adalah pada kelompok usia 1865 tahun sebanyak 77,6\%. Selain isolat dengan Proteus mirabilis tunggal, sampel juga terdiri atas kombinasi antara Proteus mirabilis dengan bakteri lainnya, seperti : Escerichia coli, Klebsiella pneumoniae dan Acinetobacter baumannii, seperti yang ditunjukkan pada tabel 1 .

Tabel 1. Mikroorganisme dari hasil kultur urin

\begin{tabular}{lcc}
\multicolumn{1}{c}{ Mikroorganisme } & \multicolumn{2}{c}{ Frekuensi } \\
\cline { 2 - 3 } & Absolut & Persentase \\
\hline Proteus mirabilis & 35 & 71.4 \\
\hline Proteus mirabilis dan Escherichia coli & 10 & 20.4 \\
\hline Proteus mirabilis dan Klebsiella pneumoniae & 3 & 6.1 \\
\hline Proteus mirabilis dan Acinetobacter baumannii & 1 & 2.0 \\
\hline \multicolumn{1}{c}{ Total } & 49 & 100 \\
\hline
\end{tabular}

Berdasarkan pemeriksaan radiologi (USG abdomen, CT Scan abdomen dan atau foto BOF) didapatkan sampel yang menunjukkan adanya batu sebanyak 13 sampel (26.5\%) dan tanpa batu sebanyak 36 sampel $(73,5 \%)$. Lokasi batu bervariasi, paling banyak berada di ginjal sejumlah 9 sampel (69.2\%), seperti yang ditunjukkan dalam tabel 2.

Tabel 2. Lokasi Batu Saluran Kemih

\begin{tabular}{lcc}
\hline \multicolumn{1}{c}{ Lokasi Batu } & \multicolumn{2}{c}{ Frekuensi } \\
\cline { 2 - 3 } & Absolut & Persentase \\
\hline Ginjal & 9 & 69,2 \\
\hline Kandung Kencing & 3 & 23,1 \\
\hline Ginjal, Ureter dan Kandung Kencing & 1 & 7,7 \\
\hline Uretra & 0 & 0,0 \\
\hline
\end{tabular}




$\begin{array}{lll}\text { Total } & 13 & 100\end{array}$

Penanda infeksi dilihat dari kadar leukosit dan persentase neutrofil pada pemeriksaan darah lengkap. Rerata jumlah leukosit adalah $13.88 \times 10^{3} / \mu \mathrm{L}$ dan rerata persentase neutrophil adalah $67.24 \%$. Sedangkan fungsi ginjal dapat dilihat dilihat dari kadar BUN dan serum kreatinin pasien. Rerata Kadar BUN adalah $27.25 \mathrm{mg} / \mathrm{dL}$, dan rerata kadar serum kreatinin adalah $2.64 \mathrm{mg} / \mathrm{dL}$. Dalam hal ini juga dibandingkan rerata jumlah leukosit, persentase neutrophil, kadar BUN dan kadar serum kreatinin antara pasien yang memiliki batu saluran kemih dengan yang tanpa batu, seperti yang ditunjukkan dalam tabel 3.

Tabel 3. Nilai Penanda Infeksi dan Fungsi Ginjal

\begin{tabular}{lccc}
\hline & Dengan Batu & Tanpa Batu & Rerata Total $( \pm$ SD) \\
\hline Leukosit (WBC) & 13,37 & 14,06 & $13,88( \pm 7,56)$ \\
\hline Neutrophil & 68,27 & 66,87 & $67,24( \pm 25,38)$ \\
\hline BUN & 33,85 & 24,86 & $27,25( \pm 26,66)$ \\
\hline Serum Kreatinin & 2,22 & 2,79 & $2,64( \pm 9,15)$ \\
\hline
\end{tabular}

Dengan menggunakan mesin otomatis (VITEC®2 Compact) diketahui pola kepekaan bakteri Proteus mirabilis terhadap berbagai antibiotik, seperti yang ditunjukkan dalam tabel 4. Persentase multidrug-resistant organisms (MDRO) pada sampel adalah $38.8 \%$ (23.1\% pada sampel dengan batu dan $44.4 \%$ pada sampel tanpa batu). Hasil sensitivitas tertinggi bakteri Proteus mirabilis adalah terhadap antibiotik Amikacin yaitu sebesar $100 \%$ (baik pada sampel dengan batu maupun tanpa batu).

Tabel 4. Persentase Sensitivitas Proteus mirabilis Terhadap Berbagai Antibiotik

\begin{tabular}{lccc}
\hline Jenis Antibiotik & Dengan Batu & Tanpa Batu & Total \\
\hline Ampicillin & 69,2 & 50,0 & 55,1 \\
\hline Cefazoline & 53,8 & 66,7 & 63,3 \\
\hline Gentamycin & 76,9 & 61,1 & 65,3 \\
\hline Amikacin & 100,0 & 100,0 & 100,0 \\
\hline Fosfomycin & 76,9 & 77,8 & 77,6 \\
\hline
\end{tabular}




\begin{tabular}{lccc}
\hline $\begin{array}{l}\text { Trimetophrim- } \\
\text { Sulfametoxazole }\end{array}$ & 46,2 & 41,7 & 42,9 \\
\hline Ciprofloxacin & 61,5 & 55,6 & 57,1 \\
\hline
\end{tabular}

\section{DISKUSI}

Proteus mirabilis merupakan uropatogen yang cukup sering ditemukan dalam praktek klinis. Data di RSUP Sanglah menyatakan 2,8\% kejadian ISK disebabkan oleh infeksi Proteus mirabilis. Persentase ini lebih kecil dibandingkan dengan hasil studi di China $(3,93 \%)$ (Yongzhi et al., 2018), Amerika Utara (4\%) dan studi di Iran (9\%) (Mirzaei et al., 2019). Secara umum ISK yang disebabkan oleh Proteus mirabilis cukup bervariasi dari berbagai studi (1$10 \%$ ) yang tergantung lokasi studi, jenis sampel yang diambil dan karakteristik pasien yang diperiksa (Schaffer \& Pearson, 2016).

Kelompok usia paling sering 1865 tahun $(77,6 \%)$ dengan jenis kelamin perempuan $(51 \%)$. Hal ini sesuai dengan studi yang dilaporkan oleh Mirzaei dkk pada tahun 2019, dengan 110 isolat Proteus mirabilis, usia pasien bervariasi antara 1 - 88 tahun (rata-rata 37,7 tahun) dan didominasi oleh jenis kelamin perempuan sebesar 71,8\% (Mirzaei et al., 2019). Pada jenis kelamin laki-laki, angka insiden ISK lebih banyak pada neonatus dan usia dewasa dengan penyakit prostat (Fusco et al., 2017).

Infeksi bakteri Proteus mirabilis

Jurnal Kedokteran

Vol. 06 No. 02 Juni 2021 pada saluran kemih cenderung memicu terbentuknya batu, akibat enzim urease yang dihasilkan oleh bakteri. Hal ini terbukti dalam penelitian ini, bahwa 26,5\% sampel ISK yang disebabkan oleh Proteus mirabilis terbentuk BSK. Bichler dkk pada tahun 2011 menyatakan angka kejadian BSK karena infeksi oleh berbagai organisme sekitar 15\% dari total BSK (Bichler et al., 2002), sedangkan menurut Jacobsen dkk bahkan bisa sampai 30\% dari total BSK (Jacobsen \& Shirtliff, 2011). BSK karena infeksi ini menjadi masalah serius karena dapat tumbuh cepat, bersifat persisten dan memiliki tingkat kekambuhan yang tinggi sampai $50 \%$ (Torzewska \& Rózalski, 2015).

Lokasi batu di saluran kemih bervariasi, pada penelitian ini paling banyak berada di ginjal $(69,2 \%)$ seperti halnya studi oleh Li dkk pada tahun 2018 dengan persentase batu ginjal sebesar 34\% (Yongzhi et al., 2018).

Fluoroquinolone merupakan golongan antibiotik yang paling sering digunakan sebagai terapi empiris untuk ISK, namun pada hasil penelitian ini memiliki angka resistansi yang cukup tinggi, begitu pula dengan ampicillin dan cotrimoxazole. Amikacin memiliki 
angka sensitivitas yang sangat baik (100\%) namun sayangnya amikacin yang diekskresikan di ginjal membuat antibiotik tersebut harus diawasi dengan baik penggunannya, terutama pada pasien dengan gangguan ginjal. Studi dari Mirzaei dkk menyatakan angka resistansi Proteus mirabilis terhadap antibiotik bervariasi dari 59,1\% (cotrimoxazole), 15,5\% (ciprofloxacin), $10 \%$ (ceftriaxone) sampai 2,7\% (coamoxicillin clavulanat). Persentase MDRO sebesar 14,6\%, lebih sedikit dari angka MDRO di RSUP Sanglah sebesar 38,8\% (Mirzaei et al., 2019).

Dalam penelitian ini ditemukan bahwa penanda infeksi seperti kadar leukosit pada pemeriksaan darah lengkap mengalami peningkatan di atas normal (rerata $13.88 \mathrm{x} 10^{3} / \mu \mathrm{L}$ ) sedangkan persentase neutrofil masih dalam kisaran normal (rerata $67.24 \%$ ). Hal ini mungkin disebabkan infeksi yang terjadi sebagian besar masih bersifat lokal di saluran kemih.

Untuk mengetahui fungsi ginjal pasien, dalam penelitian ini dipakai nilai kadar BUN dan serum kreatinin. Dengan hasil rerata kadar BUN adalah 27.25 $\mathrm{mg} / \mathrm{dL}$ (nilai rujukan normal : 10-20 $\mathrm{mg} / \mathrm{dL}$ ) dan rerata kadar serum kreatinin adalah $2.64 \mathrm{mg} / \mathrm{dL}$ (nilai rujukan normal : $0,6-1,3 \mathrm{mg} / \mathrm{dL})$, menunjukkan umumnya sudah terjadi penurunan atau gangguan pada fungsi ginjal pasien.

\section{SIMPULAN}

Proteus mirabilis merupakan uropatogen yang cukup sering menyebabkan ISK di praktek klinis selain Eschericia coli dan Klebsiella pneumoniae. Sebagaimana halnya ISK secara umum, ISK yang disebabkan oleh infeksi Proteus mirabilis juga lebih banyak ditemukan pada pasien perempuan dewasa. Infeksi bakteri ini dalam jangka waktu lama cenderung memicu terbentuknya kristal atau batu di saluran kemih pasien, khususnya batu ginjal. Dari penelitian ini, ditemukan bahwa angka sensitivitas dari Proteus mirabilis penyebab ISK terhadap ampisilin, ciprofloxacin, dan cotrimoxazole cukup rendah, sehingga penggunaan antibiotik tersebut sebagai terapi empiris harus dipertimbangkan kembali. Sedangkan amikacin dapat dipertimbangkan sebagai pilihan utama untuk terapi empiris karena memiliki tingkat sensitivitas paling tinggi. Penelitian ini juga menunjukkan bahwa ISK yang disebabkan oleh Proteus mirabilis umumnya meningkatkan penanda infeksi (kadar leukosit), begitu pula penanda fungsi ginjal pasien (BUN dan serum kreatinin). Namun dalam hal ini nilai penanda infeksi, penanda fungsi ginjal dan sensitivitas bakteri terhadap antibiotik tidak menunjukkan perbedaan yang bermakna antara pasien dengan BSK dan tanpa BSK. 


\section{KETERBATASAN PENELITIAN}

Keterbatasan penelitian ini adalah jumlah sampel yang diteliti masih sedikit sehingga memungkinkan terjadi bias. Penelitian lebih lanjut diperlukan dengan kurun waktu lebih lama untuk mendapatkan jumlah sampel yang lebih besar sehingga kemungkinan bias dapat diperkecil. Penelitian ini juga masih menggunakan studi deskriptif, sehingga variabel-variabel yang ada belum bisa dianalisis lebih lanjut.

\section{KONFLIK KEPENTINGAN}

Penulis mengungkapkan tidak ada konflik kepentingan dalam penelitian ini.

\section{REFERENSI}

Al-bassam, W. W. (2013). The Isolation and Characterization of Proteus mirabilis from Different Clinical Samples. 7(2), 24-30.

Armbruster, C. E., Mobley, H. L. T., \& Pearson, M. M. (2018). Pathogenesis of Proteus mirabilis Infection. EcoSal Plus, 8(1). https://doi.org/10.1128/ecosalplus. esp-0009-2017

Baldo, C., Paulo, S., \& Rocha, D. (2014). Virulence Factors Of Uropathogenic Proteus Mirabilis A Mini Review. International Journal of Scientific \& Technology Research, 3(11), 24-27.

Bichler, K. H., Eipper, E., Naber, K., Braun, V., Zimmermann, R., \& Lahme, S. (2002). Urinary Infection Stones. Urologia Internationalis, 41(2),

109-111. https://doi.org/10.1159/000281177

Brooks, G. F., Jawetz, E., Melnick, J. L., \& Adelberg, E. A. (2019). Jawetz, Melnick \& Adelberg's medical microbiology (28th ed.). Lange.
Chen, D., Zhang, Y., Huang, J., Liang, X., Zeng, T., Lan, C., Duan, X., Zhao, Z., Zeng, G., Tiselius, H. G., Lu, X., \& Wu, W. (2018). The analysis of microbial spectrum and antibiotic resistance of uropathogens isolated from patients with urinary stones. International Journal of Clinical Practice, 72(6), 1-9.

https://doi.org/10.1111/ijcp.13205

Fusco, A., Coretti, L., Savio, V., Buommino, E., Lembo, F., \& Donnarumma, G. (2017). Biofilm formation and immunomodulatory activity of Proteus mirabilis clinically isolated strains. International Journal of Molecular Sciences, $18(2)$. https://doi.org/10.3390/ijms180204 14

Jacobsen, S. M., \& Shirtliff, M. E. (2011). Proteus mirabilis biofilms and catheter-associated urinary tract infections. 2(5), 460-465.

Leber, A. L. (2016). Clinical Microbiology Procedures Handbook. ASM Press.

Li, X., Zhao, H., Lockatell, C. V., Drachenberg, C. B., Johnson, D. E., \& Mobley, H. L. T. (2002). Visualization of Proteus mirabilis within the matrix of urease-induced bladder stones during experimental urinary tract infection. Infection and Immunity, 70(1), 389-394. https://doi.org/10.1128/IAI.70.1.38 9-394.2002

Mahon, CR; Lechman, D. M. G. (2019). Textbook of Diagnostic Microbiology. In Elsevier (6th ed., Vol. 15, Issue 3). Elsevier. https://doi.org/10.2307/486972

Mirzaei, A., Habibi, M., Bouzari, S., \& Karam, M. R. A. (2019). Characterization of antibioticsusceptibility patterns, virulence factor profiles and clonal relatedness in proteus mirabilis isolates from patients with urinary tract infection in Iran. Infection and Drug Resistance, 12, 3967-3979. https://doi.org/10.2147/IDR.S2303 
03

Mobley, H. L. T., \& Belas, R. (1995).

Swarming and pathogenicity of Proteus mirabilis in the urinary tract. Trends in Microbiology, 3(7), 280-284.

https://doi.org/10.1016/S0966842X(00)88945-3

Norsworthy, A. N., \& Pearson, M. M. (2017). From Catheter to Kidney Stone: The Uropathogenic Lifestyle of Proteus mirabilis. Trends in Microbiology, 25(4), 304-315. https://doi.org/10.1016/j.tim.2016. 11.015

Schaffer, J. N., \& Pearson, M. M. (2016). Proteus mirabilis and Urinary Tract Infections. Urinary Tract Infections, 3(5), 383-433. https://doi.org/10.1128/978155581 7404.ch17

Torzewska, A., \& Rózalski, A. (2015). Various intensity of Proteus mirabilis-induced crystallization resulting from the changes in the mineral composition of urine. Acta Biochimica Polonica, 62(1), 127132.

https://doi.org/10.18388/abp.2014_
882

Wang, J. T., Chen, P. C., Chang, S. C., Shiau, Y. R., Wang, H. Y., Lai, J. F., Huang, I. W., Tan, M. C., \& Lauderdale, T. L. Y. (2014). Antimicrobial susceptibilities of Proteus mirabilis: A longitudinal nationwide study from the Taiwan surveillance of antimicrobial resistance (TSAR) program. $B M C$ Infectious Diseases, 14(1), 1-10. https://doi.org/10.1186/1471-2334$14-486$

Weinstein, M. (2020). CLSI M100 : Performance Standards for Antimicrobial Susceptibility Testing. In Clinical and Laboratory Standards Institute (30th ed., Vol. 30th).

Yongzhi, L., Shi, Y., Jia, L., Yili, L., Xingwang, Z., \& Xue, G. (2018). Risk factors for urinary tract infection in patients with urolithiasis - Primary report of a single center cohort. BMC Urology, 18(1), 1-6. https://doi.org/10.1186/s12894018-0359-y 